\title{
Pintoi Peanut: A Seed-propagated Perennial Peanut Forage Option for Florida ${ }^{1}$
}

\author{
Joao M. D. Sanchez, Joao Vendramini, Maria L. Silveira, Jose C. B. Dubeux Jr., Lynn E. \\ Sollenberger, and Philipe Moriel $^{2}$
}

\section{Introduction}

Pintoi peanut (Arachis pintoi; also known as pinto peanut, forage peanut, or maní forrajero) is a perennial peanut species native to South America and propagated by seeds. Pintoi peanut and rhizoma peanut (Arachis glabrata) are the two most relevant perennial peanut species used as forage; however, the first has been more extensively studied and used in South and Central America, while the second is more common in the southern United States, including Florida. Pintoi peanut is tolerant to grazing and adapted to poorly-drained, low-fertility soils. Because of its adaptability to Florida's environmental conditions and ability to produce viable seeds, pintoi peanut represents an interesting forage alternative for cow-calf producers in the state. This document provides current information on pintoi peanut for forage and livestock producers in Florida.

\section{Plant Description}

Pintoi peanut is a low-growing perennial peanut species that spreads preferentially by stolons (also known as "runners"; Figure 1), without the presence of rhizomes (subterranean stems). The leaflets are different from those of the rhizoma peanut in both color and shape. Both plants have four leaflets in each leaf; however, pintoi peanut leaflets are usually round-tipped and light green, whereas rhizoma peanut leaflets are pointed at the tip and darker green in color (Figure 2). The flowers are predominantly yellow, with some variation between white and reddish orange. The seed production is one of the advantages of pintoi peanut. It occurs in pods, similar to edible peanut species. At the base of a flower, a peg grows to a length of 2 to 13 inches and subsequently penetrates the soil surface, where it will produce a pod. Pintoi peanut pods usually contain a single seed; however, two or even three seeds may be observed (Figure 3). One of the main characteristics of pintoi peanut pods is that they drop from the pegs after maturity. This makes seed harvest more difficult because it requires soil separation from the pods.

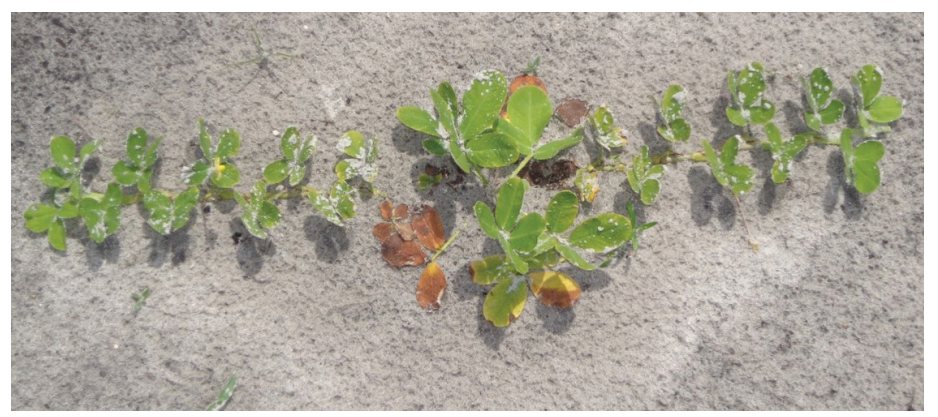

Figure 1. Pintoi peanut stolons (runners) growing parallel to the soil surface.

Credits: J. M. D. Sanchez, UF/IFAS

1. This document is SS-AGR-445, one of a series of the Agronomy Department, UF/IFAS Extension. Original publication date November 2020. Visit the EDIS website at https://edis.ifas.ufl.edu for the currently supported version of this publication.

2. Joao M. D. Sanchez, research associate, UF/IFAS Range Cattle Research and Education Center; Joao Vendramini, professor, Agronomy Department, UF/ IFAS Range Cattle Research and Education Center; Maria L. Silveira, professor, Department of Soil and Water Sciences, UF/IFAS Range Cattle Research and Education Center; Jose C. B. Dubeux Jr., associate professor, Agronomy Department, UF/IFAS North Florida Research and Education Center; Lynn E. Sollenberger, distinguished professor, Agronomy Department; and Philipe Moriel, assistant professor, Department of Animal Sciences, UF/IFAS Range Cattle Research and Education Center; UF/IFAS Extension, Gainesville, FL 32611.

The Institute of Food and Agricultural Sciences (IFAS) is an Equal Opportunity Institution authorized to provide research, educational information and other services

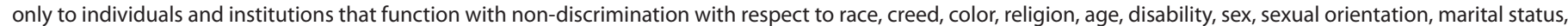

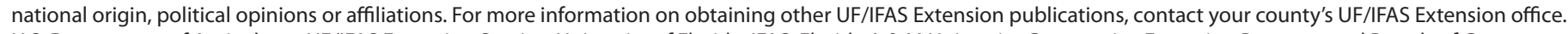
U.S. Department of Agriculture, UF/IFAS Extension Service, University of Florida, IFAS, Florida A \& M University Cooperative Extension Program, and Boards of County Commissioners Cooperating. Nick T. Place, dean for UF/IFAS Extension. 


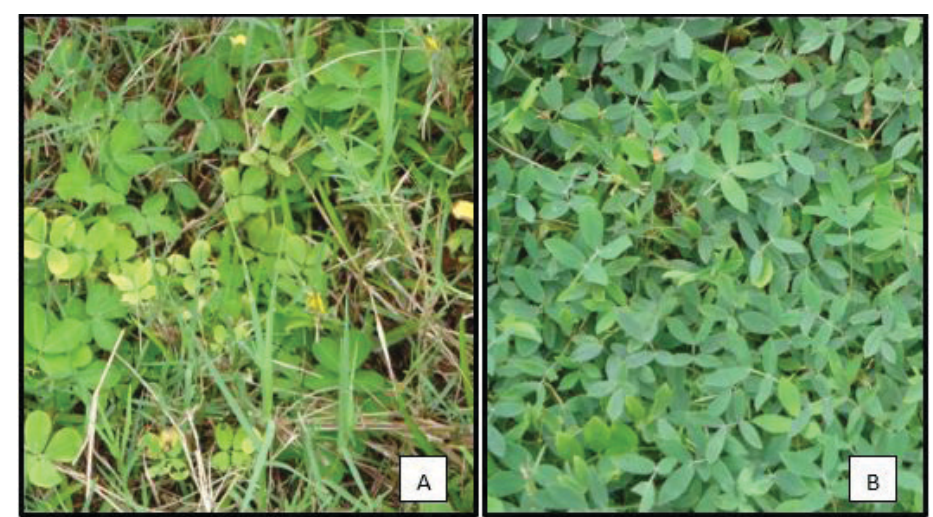

Figure 2. Comparison between pintoi $(A)$ and rhizoma (B) peanut leaflets.

Credits: J. M. D. Sanchez, UF/IFAS

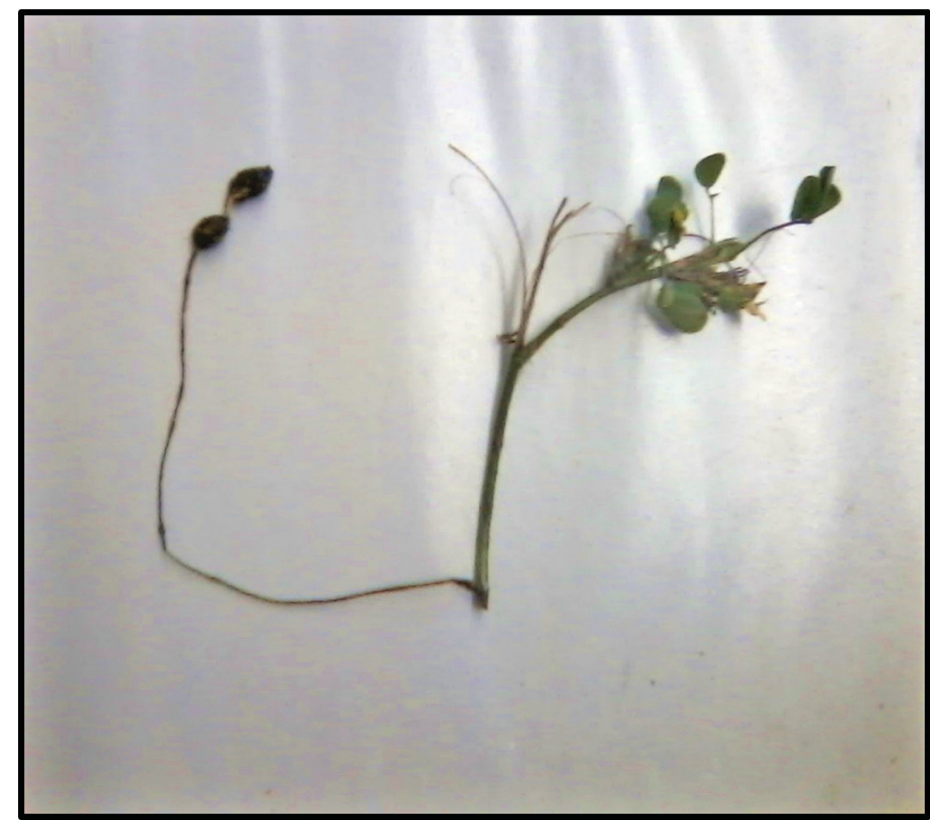

Figure 3. Part of a pintoi peanut stolon (runner) with one peg and two pods attached. Like pods of edible peanut, pintoi peanut pods remain underground.

Credits: J. M. D. Sanchez, UF/IFAS

\section{Agronomic Characteristics}

Pintoi peanut may tolerate acidic $(\mathrm{pH}=5.0)$, low-fertility soils and high soil aluminum concentrations. However, low $\mathrm{pH}$ and high soil aluminum concentrations may decrease $\mathrm{N}$ fixation and overall pintoi peanut production. The plant is adapted to different soil textures ranging from sandy to clay and is more tolerant to poorly drained soils than rhizoma peanut, which makes it an interesting option for producers in south Florida. Recent trials conducted at the UF/IFAS Range Cattle Research and Education Center showed that pintoi peanut persisted in soils subjected to intermittent (1- to 2-week) flooding conditions (Sanchez et al. 2018). Reports from International Center for Tropical Agriculture (CIAT) in Colombia indicate that pintoi peanut grows well in areas with annual rainfall ranging from 60 to 135 inches, but it also has some drought tolerance (Fisher and Cruz 1994).

Another characteristic that makes pintoi peanut a viable forage option in Florida is its frost tolerance. A study conducted in Gainesville, FL found that pintoi peanut aboveground biomass was severely damaged by frost, but plant stand survived and new stolons were produced during the rest of the growing season (spring and summer) (Carvalho and Quesenberry 2012). Additionally, pintoi peanut can tolerate shade, and it may be used as a cover crop in perennial production systems, such as orange groves.

Previous research in tropical regions showed that dry matter yields of pintoi peanut monoculture can range from 100 to 2,500 lb/acre/year, whereas crude protein and in vitro dry matter digestibility concentrations range from $13 \%$ to $18 \%$, and from $63 \%$ to $67 \%$, respectively (Rincón C. et al. 1992; Carvalho and Quesenberry 2012). The most widely used pintoi peanut cultivar is called 'Amarillo'. This cultivar was released in Australia in 1987 and it has satisfactory seed production. The general preference among producers for 'Amarillo' has been based on seed availability. Other genotypes were released in different countries, such as 'Mani Forrajero Perenne' (Colombia in 1992), 'Mani Mejorador' (Costa Rica in 1994), 'Pico Bonito' (Honduras in 1993), 'Belmonte' (Brazil in 1999), 'Amarillo MG-100' (Brazil in 1994), and 'BRS Mandobi' (Brazil in 2011), but seed availability is limited.

\section{Establishment}

Pintoi peanut may be established by both stolons and seeds in the spring and summer months. The establishment by seeds requires a seeding rate of $10 \mathrm{lb} / \mathrm{acre}$. Seeding depth in sandy soils should be around 1.5 to 2 inches, whereas seeding in heavier soils should be around 1 inch. The use of specific inoculants may be beneficial for the establishment of pintoi peanut, but availability of inoculant in the US may be restricted. The effectiveness of other inoculants, such as commercial products used for cowpea or clover, has not been determined. If vegetative material is used for establishment, stolons should be planted in 4-inch-deep rows, with between-row spacing of 20 inches.

Pintoi peanut has slow establishment that may take multiple growing seasons for full ground cover. Research conducted in Gainesville, FL, concluded that pintoi peanut ground cover one year after planting was still less than $50 \%$ (Carvalho and Quesenberry 2012). There are no registered selective herbicides that can be applied to pintoi peanut fields. Herbicides recommended for rhizoma peanut 
(perennial peanut species commonly used in Florida) may damage pintoi peanut stands.

It is recommended to seed pintoi peanut with warm-season perennial grasses, such as bahiagrass and bermudagrass. One of the strategies to include pintoi peanut in these mixtures is to seed it simultaneously with grass planting. An experiment conducted at the UF/IFAS Range Cattle Research and Education Center in Ona, FL, showed that seeding pintoi peanut either as monoculture or simultaneously with bahiagrass made no difference in pintoi peanut spread and productivity (Sanchez et al. 2019). However, when pintoi peanut was seeded as monoculture, there was a greater weed infestation even one year after the seeding. Infestation decreased gradually when pintoi peanut was seeded in mixture with bahiagrass (Figure 4). Similar observations were reported by Jaramillo et al. (2018b) in a study where pintoi peanut was simultaneously planted with 'Tifton-85' bermudagrass (Cynodon spp.). Pintoi peanut may also be overseeded into existing pastures. It has been observed that pintoi peanut established well in preexistent pastures of 'Pensacola' bahiagrass (Jaramillo et al. 2018a) and Jiggs bermudagrass (Sanchez et al. 2018).

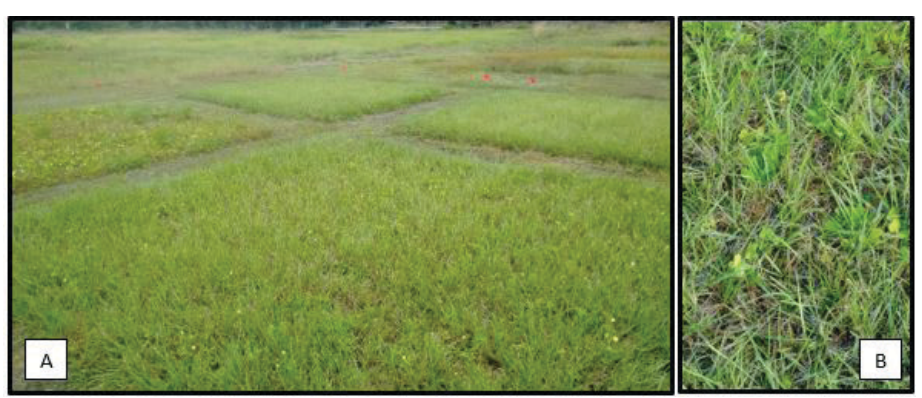

Figure 4. Bahiagrass-pintoi peanut mixed plot (yellow flowers are from pintoi) in broad $(A)$ and close $(B)$ views.

Credits: J. M. D. Sanchez, UF/IFAS

\section{Management}

Pintoi peanut has a prostrate growth habit with growth points often protected from defoliation at low stubble heights. Researchers in Australia observed that pintoi peanut persisted in a grass-legume mixture when stubble heights ranged from 2 to 4 inches (Sinclair et al. 2007). In some pintoi peanut-grass mixed pastures, pintoi peanut may be favored by lower stubble heights. In Brazil, researchers observed that pintoi peanut proportion in a grass-legume mixture with palisadegrass increased from $4 \%$ to $14 \%$ when stubble height decreased from 14 to 8 inches (Andrade et al. 2012). A few studies were conducted at the UF/IFAS Range Cattle Research and Education Center, evaluating pintoi peanut's adaptation to different management practices and its use in mixture with warm-season perennial grasses. Results demonstrated that pintoi peanut proportion and spread when overseeded in a Jiggs bermudagrass pasture were similar when grazed at stubble heights of 6 or 12 inches (Sanchez et al. 2018), and that pintoi peanut persisted at both stubble heights. Time after planting is an important factor in the initial years after seeding; the legume's proportion in herbage mass increased during the two years of the experiment (Table 1). Another study conducted at the UF/IFAS North Florida Research and Education Center in Marianna, FL, showed that pintoi peanut proportion in a grass-legume mixture with Tifton 85 bermudagrass was below 5\% during the first and second years after seeding, reaching $17 \%$ on the third year (Jaramillo et al. 2018a). Given its grazing tolerance, low productivity, and prostrate growth habit, pintoi peanut should be mainly mixed with other tropical grasses, and used for grazing instead of hay production.

\section{References}

Andrade, C. M. S. De, R. Garcia, J. F. Valentim, and O. G. Pereira. 2012. "Productivity, Utilization Efficiency and Sward Targets for Mixed Pastures of Marandugrass, Forage Peanut and Tropical Kudzu." Rev. Bras. Zootec. 41(3): 512-520. doi: 10.1590/S1516-35982012000300006.

Carvalho, M. A., and K. H. Quesenberry. 2012. "Agronomic Evaluation of Arachis pintoi (Krap. and Gre.) Germplasm in Florida." Arch. Zootec. 61(233): 19-29.

Fisher, M. J., and P. Cruz. 1994. "Some Ecophysiological Characteristics of Arachis pintoi." In Biology and Agronomy of Forage Arachis, edited by P. C. Kerridge and B. Hardy. 169-186. Cali, Colombia: CIAT: Centro Internacional de Agricultura Tropica.

Jaramillo, D. M., J. C. B. Dubeux, Jr., C. Mackowiak, L. E. Sollenberger, N. DiLorenzo, D. L. Rowland, A. R. S. Blount, E. R. S. Santos, L. Garcia, and M. Ruiz-Moreno. 2018a. "Annual and Perennial Peanut Mixed with 'Pensacola' Bahiagrass in North Florida." Crop Sci. 58(2): 982-992. doi: 10.2135/cropsci2017.09.0542.

Jaramillo, D. M., J. C. B. Dubeux, Jr., C. Mackowiak, L. E. Sollenberger, E. R. S. Santos, L. Garcia, M. Ruiz-Moreno, C. S. Silva, and N. DiLorenzo. 2018b. "Annual and Perennial Peanut Species as Alternatives to Nitrogen Fertilizer in Bermudagrass Hay Production Systems." Agron. J. 110:2390-2399. doi: 10.2134/agronj2018.01.0036. 
Rincón Castillo, A., P. A. Cuesta Muñoz, R. A. Pérez Bonna, C. E. Lascano, and J. E. Ferguson. 1992. "Maní forrajero perenne (Arachis pintoi Krapovickas y Gregory): Una alternativa para ganaderos y agricultores." Cali, Colombia.

Sanchez, J. M. D., J. M. B. Vendramini, M. L. Silveira, L. E. Sollenberger, J. C. B. Dubeux, Jr., P. Moriel, B. Sellers, J. K. Yarborough, and F. C. Leite de Oliveira. 2019. "Seeding Strategies of Bahiagrass and Pintoi Peanut Affect Pasture Establishment under Weed Competition." Grass Forage Sci. 74(3): 381-388. doi: 10.1111/gfs.12413.

Sanchez, J. M. D., J. M. B. Vendramini, L. E. Sollenberger, M. L. Silveira, J. C. B. Dubeux, Jr., P. Moriel, F. Kuwahara, et al. 2018. "Forage Characteristics of Bermudagrass Pastures Overseeded with Pintoi Peanut and Grazed at Different Stubble Heights." Crop Sci. 58(4): 1808-1816. doi: 10.2135/ cropsci2018.01.0007.

Sinclair, K., K. F. Lowe, and K. G. Pembleton. 2007. "Effect of Defoliation Interval and Height on the Growth and Quality of Arachis pintoi cv. Amarillo." Trop. Grasslands 41(4): 260-268. 
Table 1. Pintoi peanut plant population, cover, and biomass production in a grass-legume mixture with Jiggs bermudagrass. Data are expressed according to stubble height treatment (6 or 12 inches), as well as the beginning and end of a two-year experiment (2014 and 2015). Adapted from Sanchez et al. (2018).

\begin{tabular}{|c|c|c|}
\hline \multirow[t]{2}{*}{ Response Variable } & \multicolumn{2}{|c|}{ Stubble Height (inches) ${ }^{1}$} \\
\hline & 6 & 12 \\
\hline Pintoi peanut ground cover (\%) & 6 & 6 \\
\hline Pintoi peanut plants/sq. ft. & 0.5 & 0.5 \\
\hline \multirow[t]{3}{*}{ Pintoi peanut proportion of total biomass (\%) } & 3 & 3 \\
\hline & \multicolumn{2}{|c|}{ Year $^{2}$} \\
\hline & 2014 (Initial) & 2015 (Final) \\
\hline Pintoi peanut proportion of total biomass (\%) & 1 & 8 \\
\hline
\end{tabular}

